\title{
Justice at Sport Clubs According to the Theory of Utilitarianism and Libertarianism
}

Authors' contribution:

A) conception and design of the study

B) acquisition of data

C) analysis and interpretation of data

D) manuscript preparation

E) obtaining funding

\author{
Róbert G. Zimányi ${ }^{\mathrm{A}, \mathrm{B}, \mathrm{C}, \mathrm{D}, \mathrm{E}}$, Gábor Geczi ${ }^{\mathrm{A}, \mathrm{C}, \mathrm{E}}$
}

University of Physical Education, Hungary, Budapest

ABSTRACT

Today's sport clubs are exposed to turbulently changing circumstances to which they must adapt. If we want to talk about quality sport clubs, we have to find the qualitative criterion that justifies them. This must then be accepted by society as well. Such aspects of quality and evaluation may show justice. Only one truth exists. Thus the question is how and by what principles we should interpret it. Justice can play a key role in the operation of sport clubs as a moral element. This justice must not necessarily be linked to equality. The goal of this study is to interpret justice as a quality factor in sport clubs. The other goal of the study is to present some theories of justice related to sport. The study examines Bentham's utilitarianism, Mill's higher pleasures, and the ideas of libertarianism concerning justice. The theories of justice in addition to social processes also play a key role in today's sport clubs. During the interpretations, it is important to distinguish between competitive and non-competitive sport clubs in relation to justice. It also depends on the practical applicability of the theory of justice. The practical application of theories of justices should be thoroughly investigated in the life of sport clubs. Then the sport clubs' management must decide which theory of justice should be introduced. The key question concerns how to apply it consistently in practice while taking into account the interests of existing and prospective members. Finding the potential qualitative key factors for the sport clubs' qualification is a complex activity. Besides happiness and justice, many other ancient and presently valued virtues can be relevant qualities and distinctive aspects among sport clubs.

KEYWORDS

quality, justice, utilitarianism, libertarianism, sport clubs

\section{Introduction}

The goal of sport clubs is qualitative positive distinction. As sport clubs are also exposed to turbulently changing external conditions, they must first adapt. If this process is successful, then they must have as effective a role as possible. According to a previous study, happiness can be an influential and distinctive role among sport clubs (Zimányi \& Vermes 2016). If we want to talk about quality sport clubs, it is necessary to find the qualitative criteria certifying them. These criteria should not only be evaluated, but must also be accepted by society. In addition to happiness, such quality and evaluation criteria can be a form of justice and can also play a distinctive qualitative role in today's sport clubs. Only one truth exists. The question is how and by what principles do we interpret it? Justice can play a key role in the operation of sport clubs as a moral element. This justice must not necessarily be linked to equality. 
Because sport is a subsystem of society, Sandel's issues referring to this and related to justice (Sandel 2009) can also be adapted for sport clubs. Possible questions may arise: In the case of a disaster, does a sport club have the right to raise its annual membership fees? Can somebody sacrifice an athlete's victory for the top positions of teammates or in order to avoid falling out of a competition system? Is it acceptable if a competitor is overtrained to the point of falling down in a faint? Should the same membership fees be paid by competitive and non-competitive athletes?

We can ask questions related to justice at sport clubs: When does a sport club behave fairly against its members? Should a sport club follow a utilitarian view that gives most members the most benefits? Or should it represent libertarian ideas, according to which any limitation of people is immoral? It can be seen that countless theories of justice can be discovered, and in all of them truth can be observed. We cannot follow all of them: a sport club must also choose the most appropriate theory of justice for itself that it desires to follow faithfully in its mission and vision.

\section{The general interpretation of justice}

The goal of the study is to interpret justice as a quality factor at sport clubs. What does truth mean? What does justice mean? The answer is in dividing the most important things in the right way, as we deserve to have them (Sandel 2009). However, the question arises as to what we deserve and why. It is important in the future in terms of interpretation to approach the question from a moral point of view.

The purpose of this study is to present the following theories of justice in practice: Bentham's utilitarianism, Mill's higher pleasures, and libertarianism's thoughts on justice. If we talk about any of the abovementioned theories of justice, these truths can play a key role at sport clubs, just as in social processes. Processing these theories of justice, the study presents potential sport clubs' justice, including which theory is chosen and applied in practice. These may cause differences in quality among sport clubs.

In the following, the above theories of justice are examined in this study (Sandel 2009). Then these theories will be adapted to the functioning of today's sport clubs. Before these theories of justice are discussed in connection with sport clubs, sport clubs should be briefly discussed. How can we interpret them? In the analysis of justice, we distinguish between competitive and non-competitive sport clubs - the latter can also be called recreational sport clubs. There are, of course, sport clubs with common features focusing on both competitive and recreational elements. The main point is to meet the needs of the members. However, based on the study, the competitive and non-competitive nature will be distinguished for the purpose of understanding the issue of justice related to sport clubs. In the present circumstances, the company sport, which was featured separately for "Happy Sport Clubs" (Zimányi \& Vermes 2016), will not be examined. The reason is that the interest of the company stands in the focus of the company sport's justice. Thus, theories of justice could not be interpreted independently from the telos. In the case of company sports, sport does not always stand as the focus. Other economic factors may play a role and prevail.

In the following, we study these theories of justice and describe how and when they should be used in sport clubs every day.

\section{The principle of greatest happiness - Bentham's utilitarianism}

This justice theory is the same as utilitarianism. Bentham is the founder of utilitarianism and dealt with the maximization of happiness. According to him, pleasure must be greater than pain. All actions that seek as much pleasure as possible and as little pain as possible are correct and fair. The goal is to have more enjoyment for more people, and at the same time less pain (Bentham 1996). There are objections to Bentham's philosophy: it does not pay sufficient attention to freedom and minority rights (the former is of the utmost importance for Mill, who is also a utilitarian). The other issue is more complicated: every person is different. What can be an acceptable common standard for everyone? In order to determine this, cost-benefit analysis can help if we can quantify everything. Based on cost-benefit analysis, everything can be measured. Everything can be expressed, even in cash, so we can make a decision based on numbers. The theory can work; however, would we really act this way in practice? All of this is possible only if we can bring pleasure and pain to a common denominator. 
How can we use utilitarianism in the case of sport clubs? What does the most pleasure and least pain mean for the people here? Will we sacrifice someone's victory in a competitive sport for the success of others? Or will we exclude a member who destroys the community at a recreational sporting event? In the latter case, according to this principle, if somebody reduces the utility of others, this is a fair solution for the other members. What about "sacrificing" in the field of competitive sports? It's the same as in non-competitive sports. Based on the principle of utility, the success of a competitor can be sacrificed if it means that the others reach even better results. It is not that with one man falling out everybody gets ahead by one place, as this would not meet the telos of competitive sport (Zimányi \& Vermes 2016). Think of the example of a bicycle race: whoever dictates the pace is unable to ride to the end, so for him there is no chance of winning. But the others (who are also members of the sport club) are thus able to win the competition (as a team). The operation is based on an economic principle: What is the interest of the majority of society and the members of sport clubs? Which theory is not afraid of the members' sanctioning? These two examples are also true for maximizing happiness, even at the community (sport club) level. Following the principle of utility by sport clubs, every pleasure needs to be maximized, whether that be a competitive or recreational sport success. Meanwhile, we have to minimize the pain: negative sport results, unpleasant community sporting events, etc.

What about individual freedoms? If there are no human values, in the utilitarian point of view we can do anything for utility. We only treat athletes "as an asset" whose sport results the leaders of sport clubs can sacrifice in order to reach the greatest utility, referring to utilitarian justice. This can work in the field of competitive sports and recreational sports as well. Nowadays, social aspects have come to the fore that also play a major role in the life and operation of sport clubs. What is the common standard of values? If everything is measurable and expressed through cost-benefit analysis, then it is not difficult to determine which decisions provide the most benefits and which athletes should be "sacrificed," played in a key position, or contracted to us (Zimányi 2016). However, we must be aware that in the field of the social sciences, not everything can be expressed purely by numbers; every process may have different positive and negative effects. How can we calculate all of these: human happiness, human values, damage or compensation value? Are we sure that we will reach a higher utility if we deprive a competitor (athlete) ${ }^{1}$ of success for the sake of other competitors (athletes)? Here's an analogy for recreational sport: Should a member be excluded who has destroyed the community spirit only one time? It could be that this only happened once, and at other times he was the group's soul and motivating spirit. Each member of a sport club should be treated in the same way (without any discrimination). With the utilitarian point of view, who knows who will bring the most benefit to the sport club in the future? In the aforementioned cases, it could be that a competitor (athlete) would reach many great records. If he was not deprived of first place, he would generate even greater (financial, prestige-like) utility for the sport club. The results achieved in competitive sport can be quantified, providing predetermined material benefits. However, the principle of the greatest utility is not limited to material-like utility, but maximizing happiness is difficult to measure. In the case of recreational sport, if a sportsman who (for some reason) was having a bad day was not excluded, it is possible that he would recruit additional members. These new members would be able to continue to build the community. Furthermore, this also brings economic benefits to sport clubs through membership fees. The issue of negative and positive external effects can be brought up, but this depends on the future utility that sport club members can bring. A more accurate mapping and determination of this would require further investigation, as well as a measurement of maximizing happiness. This study does not deal with the latter.

\section{Mill's utilitarianism and the higher pleasures}

Mill also defended utilitarianism against its critical reviewers, but in a "more humane" form than Bentham (Mill 1979). Comparison and reconciliation of the individual freedom and utilitarianism is his focus in ethics. People can do anything that they want - there is only one precondition: it is not allowed to hurt

\footnotetext{
${ }^{1}$ In the study, there is not a significant difference between the words "athlete" or "competitor." "Athlete" means a person who carries out sports activities. "Competitor" is someone who engages in a competitive sport as part of a competitive system.
} 
others, and the state cannot restrict freedom (Mill 1989). Utility is the basis of ethical issues, but utility should be maximized in the long run. It must be made clear that the opinion of the majority may not be correct. According to Mill, conformity is the greatest enemy of a righteous life. He draws attention to the importance of not imitating or following habits. Instead, people should use their capabilities to reach the greatest human happiness - respecting individual freedom. In Mill's philosophy, the higher pleasures play a key role. In his view, a distinction should be made between lower and higher pleasures. Higher pleasures can result in stronger and longer-term pleasures, which lead to happiness. Quantity counts, even if it is not possible to fully compare the items (it could only be possible with cost-benefit analysis, which is appropriate for the purpose). With Bentham's consistent, but less humane, approach, who should decide which pleasures are higher and why? According to Mill, we can only make a distinction on the basis of utility. Moral ideas and quality do not influence what would be more appropriate individually or socially. The difference is that one of them is preferred for some reason; one of them is better than the other. In his opinion, the higher human abilities are attractive, and the basis is the ideal of the human dignity, which is independent from needs and desires. We do not prefer one over the other, but we are aware of the higher one. It catches our highest abilities and makes us more perfect people (Sandel 2009).

How would Mill's philosophy be applied to sport clubs? A competitor can do anything when playing a sport, but he cannot hurt his opponents, his teammates, or anyone entering into the world of sport. This principle can also work within a sport club. For example, in connection to the utility of sport clubs, a footballer passes less to other players to achieve more goals for his team. However, he should not completely rule out his teammates. Likewise, no one is considered a winner if he deliberately puts his teammates in a worse position, thereby causing them a disadvantage. This idea also includes the issue of fair play, but the present study does not deal with this topic. For the analogy of the state, a sport club cannot restrict rights. But sacrificing for utility according to Bentham cannot work without the consent of the other party if that person is put into a worse situation, even if it is in the interest of the sport club. How does higher pleasure look in sport clubs? What can we consider as appropriate? Based on utility, we can prioritize in this way: for some reason, one piece of sport equipment or one teammate is preferred over another. In the interests of the team, we can decide what the higher pleasures are. This means that the greater the utility, the higher the happiness. For example, in a team sport, the coach has to designate the lineup in a way that allows the team to reach the greatest utility. Thus, it can contribute to higher pleasures if a teammate in a key situation gets the chance to maximize the pleasure and move the team to victory. Not everyone can elicit and reach this higher pleasure. The task of the coach is to find these people. In the case of team games (for example, in football), we have to give the person who is the most "goal-sensitive" and has ability to score goals an opportunity to do so. This process can not only help the team, but also help in reaching individual fulfilment. It is important to note that the latter is only possible if they do not harm others, so that the teammates and other sport rights are not violated. The rights are not violated if someone does not give the ball to his other teammates. In the worst case, the telos of the team sport does not prevail properly. Bentham and Mill were concerned with death as well (Sandel 2009). As an analogy, we can ask the following question: What should be left for a sport club? We are convinced that a sport club should use the spiritual heritage anyway, inspiration from the thoughts of former famous competitors and sport club leaders. The best practices inspire us as well, and could even - decades later - serve the greatest utility for the current management (a sport club always has to adapt to the circumstances).

Nozick's questions may also apply to sport clubs: Did the sport club acquire the wealth legally? Was it in the form of a free market exchange, or did the sport club gain its wealth from volunteer gifts (for example, donations, contributions, or subsidies)? If the answer is yes to both, it can legitimately maintain possession. If the answer is no, a sport club can live with tax and compensation obligations, but it does not help in creating equality. Some sport stars earn so much because some people want to see them out of their own free will. In fact, they are willing to pay to do so. This is fair from the following point of view: Those who do not want to see them do not visit the event and do not pay for it. It is a consequence of free choice. However, if the state imposes taxes on these competitors, it violates their free rights. It is like they're working for them, and thereby they partially own them. The athletes possess their bodies, and no one limits them in what they do. This is a 
key issue in the field of competitive sport, where the body's hard physical use is typical for success in many sports. But according to this theory, the athletes should not be protected from themselves, not even if there is the possibility of injury due to physical activity (which contradicts the aforementioned Sandel comment, listed first). Depending on the circumstances, free will is more tied to the nature of competitive sport. A recreational sportsman may decide by his own free will or internal motivation whether or not he wants to do an activity. This is not how he makes a living; he looks at sport as recreation. However, for a competitor, the economic aspect plays a key role. A competitor must carry out sport activities, even if he does not feel enough motivation at the moment. Thus, free will is questionable. For sport clubs, it is a citizen's duty that individuals deal with their bodies through activity and sports for their own health. They do not look at their bodies as objects, but with dignity and respect. This may be a mandatory requirement for sport clubs that they cannot replace. Voluntary commitment is needed, not "sports mercenaries."

\section{Conclusions}

There are many theories of justice. Should this be any justice-related view, we could apply it to sport clubs in the same way as any other area of society - just one truth exists, but that does not determine which theory and approach will be accepted. Justice cannot be separated from the evaluation, and it is also a quality criterion of sport clubs. We must be aware that these issues relating to justice are moral questions as well. They are interconnected with, among other things, virtue, esteem, pride, and recognition. Justice is about (besides the right way to distribute goods) how to evaluate processes and events correctly (Sandel 2009). There are countless competitive and non-competitive (recreational) sport clubs around the world that follow different theories of justice during their operation. A sport club's leadership has to reasonably decide which theory of justice they want to follow. The decision must be made that best represents the interests of the sport club. The selection can be made empirically, after trying to apply more theories of justice. The selected theory of justice must be applied in practice, in the interest of credibility. It is advisable to make a decision that cooperates with society and focuses on the target groups relevant to them through prioritization.

A sport club's leadership cannot be liberal neutral because they have to determine the guidelines. In relation to the theory of justice that has been selected, introduced, and applied in practice, the current sport club members can decide whether or not they can identify with this sport club model of justice. If they can, they will remain members. If they cannot, they can use the interest enforcement tools or they may decide to exit. "The exit from a sport club" is a complex issue that is not addressed in this study because of several elements that can play a key role in the exit, such as identity, loyalty, or commitment. They may all prevent the exit, but more research is needed to clarify this issue. New members who can identify with the leadership have the opportunity to join the sport club as well because the sport club's management defines a theory of justice to be followed. In the sport club's life, the practical application of theories of justice should be thoroughly investigated. Based on this, the sport club has to decide which theory of justice should be followed for quality and for positive judgment. After the decision is made, another key question can be raised: How can the selected theory of justice be applied in practice to the existing and future prospective members? "We can follow any theories of justice. However, if we talk about justice at sport clubs, the telos (related to sport and sport clubs) must always be fulfilled" (Zimányi \& Vermes 2016).

\section{Future research areas}

The present study does not extend to Aristotle's thoughts on justice and fairness, which are based on teleological thinking with the definition of the telos. According to Aristotle, the discussion of justice is about virtue, respect, the nature of a good life, and compliance (Aristotle 2011). Besides Aristotle, many other theories of justice can also be researched in connection with sport clubs. Should we use the justice theory by Kant? Or should a sport club follow Rawls' thinking about equality? Or perhaps Nozick's ideals of justice should be authoritative? Should a sport club apply a meritocratic system or, regardless of merit, offer full equality between the sport club members? How should a handicapped sport club be handled? Is positive discrimination the best solution within a sport club? If so, along what arguments can we support the basis of justice? For the qualification of a sport club, finding the potential key quality factors is a difficult and complex 
task. Besides the issues of happiness (Zimányi \& Vermes 2016) and justice, many other ancient and presently valued virtues can be relevant as distinguishing determinants of quality between sport clubs. These quality factors can help us make the right choice of where would we like to engage in sport activities. In addition to these virtues, other (perhaps they could be called "external") elements can be qualitative criteria and factors. These (external) factors may be infrastructure, the quality of the sport facilities, economic operation, the number of fans, network of relationships, resupply and youth education, etc.

\section{REFERENCES}

Aristotle (2011). Nicomachean Ethics. Chicago and London: The University of Chicago Press.

Bentham, J. (1996). Introduction to the Principles of Morals and Legislation. Oxford: University Press.

Friedman, M. (1962). Capitalism and Freedom. Chicago, IL: University of Chicago Press.

Kant, I. (1964). Groundwork for the Metaphysics of Morals. New York, NY: Harper Torchbooks.

MacIntyre, A. (2007). After Virtue ( $3^{\text {rd }}$ ed.). Notre Dame, IN: University of Notre Dame Press.

Mill, J.S. (1989). On Liberty. Cambridge: University Press.

Mill, J.S. (1979). Utilitarianism. George Sher, ed. Indianapolis, IN: Hackett Publishing.

Nozick, R. (1974). Anarchy, State, and Utopia. New York, NY: Basic Books.

Rawls, J. (1971). A Theory of Justice. Cambridge, MA: The Belknap Press of Harvard University Press.

Sandel, M.J. (2009). Justice: What's the Right Thing to Do? New York, NY: Farrar, Straus and Giroux.

Simon, R.L., Torres, C.R., \& Hager, P.F. (2015). Fair Play: The Ethics of Sport (4th ed.). Boulder, CO: Westview Press.

Warburton, N. (2012). A Little History of Philosophy. New Haven, CT: Yale University Press.

Zimányi, R. (2016). Sportolók és sportegyesületek közötti minőségi szerződéskötések és átigazolások = Quality contracts and transfers between athletes and sport clubs. In: Keresztes Gábor (Ed.), Tavaszi Szél 2016 = Spring Wind 2016. Tanulmánykötet. IV. kötet: Pszichológia- és neveléstudomány, sporttudomány, szociológia- és multidiszciplináris társadalomtudomány, történelem- és politikatudomány (p. 503) = Book of studies. IV. volumes: Psychology and Pedagogy, Sport Science, Sociology, multidisciplinary Social Science, History Science and Political Science (p. 503).

Zimányi, R. \& Vermes, K. (2016). Happy Sport Clubs. In: A. Gál, J. Kosiewicz, \& T. Sterbenz (Eds.), Sport and Social Sciences with Reflection on Practice (pp. 117-128). Warsaw: AWF-ISSSS.

AUTHOR'S ADDRESS: Róbert Zimányi

University of Physical Education

School of Doctoral Studies

1112 Budapest, Rozsabarack u. 14

Hungary

E-mail: zimanyi.robert@evopro-sc.com

Received: 24 November 2017; Accepted: 10 January 2018 